\title{
МЕЖОБЩИННЫЕ КОНФЛИКТЫ В УСЛОВИЯХ ТРАНСФОРМАЦИИ КОНФЕССИОНАЛЬНОГО ГЕОПРОСТРАНСТВА (НА ПРИМЕРЕ НИГЕРИИ)
}

\author{
И.А. Захаров ${ }^{1}$, Р.В. Дмитриев ${ }^{2}$ \\ ${ }^{1,2}$ Институт географии РАН \\ ${ }_{1,2}^{1,}$ Институт Африки РАН \\ ${ }^{1}$ Науч. с.; канд. геогр. н., мл. науч.с.; е-mail: vanszax@yandex.ru \\ ${ }^{2}$ Cт. науч. с.; канд. геогр.н.; e-mail:dmitrievrv@yandex.ru
}

\begin{abstract}
В статье предпринимается попытка определить пространственные механизмы возникновения конфликтов в условиях трансформации конфессионального пространства Нигерии. Для реализации поставленной задачи предлагается авторская методика, позволяющая определить векторы и тенденции трансформации геопространств крупнейших религий Нигерии - христианства, ислама и этнорелигий - в пределах ее административно-территориальных единиц. В основу методики положены индексы структурных различий Рябцева и Херфиндаля-Хиршмана, динамика значения доли адептов религий, скорость и траектория движения демографических центров религий внутри страны. Полученные результаты были сопоставлены с географией столкновений, которые рассматривались с учетом их основных субъектов, масштаба (среднее число жертв одного столкновения) и жестокости (доля жертв одного столкновения). Определено, что расширение геопространств христианства и ислама было обеспечено прежде всего за счет сжатия геопространства этнорелигий и привело к образованию диагонально вытянутого пояса, который разделил Нигерию на преимущественно христианский юг и мусульманский север. Сложившаяся поляризованная территориальная структура конфессионального пространства Нигерии на фоне серьезных социально-экономических диспропорций между южными и северными штатами привела к увеличению конфликтного потенциала этой страны. Эмпирически установлено, что жестокость конфликтов в Нигерии повышается по мере движения на северо-восток, т. е. соответствует вектору расширения геопространства христианства. Авторы интерпретируют обнаруженную закономерность как ответную реакцию геопространства ислама на замещение со стороны более успешного в рамках своей миссионерской деятельности христианства. При этом наиболее активные субъекты конфликтов, в частности группировка «Боко Харам» (запрещена в РФ), возникли в историческом ядре ислама в Нигерии, а не в зоне непосредственного взаимодействия мировых религий. Имеющиеся данные указывают, что масштаб и жестокость столкновений в Нигерии тем выше, чем стремительнее протекают процессы трансформации в конфессиональном пространстве ее административно-территориальных единиц.
\end{abstract}

Ключевые слова: Африка, география религий, конфессиональное геопространство, религиозная конкуренция, религиозный конфликт

\section{ВВЕДЕНИЕ}

Ни один другой макрорегион мира не столкнулся с такой масштабной трансформацией конфессионального пространства, как Африка в XX в. К началу XXI в. геопространство этнорелигий, адепты которых ранее составляли абсолютное большинство населения континента, оказалось поделено между мировыми религиями: бо́льшая его часть отошла христианству (юг), меньшая - исламу (север страны). С исчерпанием конверсионного ресурса этнорелигий геопространства ислама и христианства начали активно взаимодействовать в Судано-Сахельском коридоре [Захаров и др., 2020б]. Сложившаяся территориальная структура конфессионального пространства Африки на фоне действия других факторов имела своим эффектом рост числа и масштаба конфликтов, в том числе на религиозной почве. В результате континент стал одним из наименее стабильных макрорегионов мира - только за период с 1997 по 2017 г. на него пришлось более 140 тыс. столкновений, унесших жизни почти 700 тыс. человек [Africa..., 2018].

Конфессиональные различия обычно рассматриваются в научной географической литературе как одна из предпосылок к формированию в пределах отдельных государств разломов, к которым приурочен наибольший риск сепаратизма [Заяц, 2004], сецессионизма [Попов, 2012], возникновения непризнанных государств [Заяц, 2020] и неконтролируемых территорий в результате фрагментации политического пространства на разных территориальных уровнях [Колосов и др., 2021; Себенцов, Колосов, 2012]. Другим смежным направлением исследований является изучение пространственных закономерностей локализации конфликтов, которые так или иначе мотивированы религиозными и квазирелигиозными убеждениями [Захаров и др., 2020a; Brazhalovich et al., 2016], а также оценка 
рисков территориальной экспансии деятельности радикальных исламистских организаций [Dmitriev et al., 2020; Walther, 2009]. В отечественных и зарубежных географических, так же как и в смежных политологических и социологических исследованиях, отмечается значимость религиозного фактора в развитии конфликтов в современной Африке, но при этом пространственные механизмы их действия остаются практически без внимания.

Ранее на примере Африки нами было установлено, что значительная часть конфликтов приурочена к зонам меж- и внутрирелигиозной конкуренции и возникает в ходе или после трансформации конфессионального пространства стран континента [Захаров и др., 2020а]. Однако результаты, полученные нами на уровне стран, не позволяют в полной мере раскрыть пространственные механизмы возникновения конфликтов в условиях трансформации конфессионального геопространства. Достижение этой задачи представляется возможным на более низком территориальном уровне.

В качестве полигона исследования была выбрана Нигерия, для которой, во-первых, характерен высокий удельный вес в конфессиональном пространстве Африки: в 2010 г. это государство занимало первое место по численности адептов всех крупнейших религий (15,7\% христиан макрорегиона, 16,8\% мусульман и 15,1\% адептов этнорелигий) [Brown, James, 2019]. Во-вторых, конфессиональное пространство Нигерии расколото практически на равные по численности христианский юг и мусульманский север. При этом такое разделение страны носит не абстрактный характер, а проявляется во многих аспектах жизни нигерийского общества [Tolerance..., 2010]. В-третьих, Нигерия входит в конфликтную зону стран бассейна озера Чад и является одним из наиболее конфликтных государств африканского континента - оно занимает четвертое место после Сомали, Конго и Судана по числу столкновений и пятое место по количеству жертв. При этом основными субъектами конфликтов в Нигерии являются радикальные исламистские организации, такие как «Боко Харам» (террористическая организация, запрещенная в РФ) [Фитуни, 2015].

\section{МАТЕРИАЛЫ И МЕТОДЫ ИССЛЕДОВАНИЯ}

В силу особенностей структуры конфессионального пространства Нигерии и высокого уровня религиозности населения вопрос о вероисповедании является настолько чувствительным для нигерийского общества, что правительство решило исключить его из переписи населения. Это несколько затрудняет исследование конфессионального пространства страны. Тем не менее нам удалось собрать доста- точный статистический материал по административно-территориальным единицам (АТЕ) первого порядка Нигерии для анализа динамики их конфессионального пространства. Он базируется на двух группах данных: 1) результаты переписей населения в 1952 и 1963 гг., приведенные к современным границам АТЕ Нигерии [Ostien, 2012]; 2) результаты выборочных социологических опросов населения, проведенных в рамках исследовательского проекта «Афробарометр» в 2005 и 2015 гг. [Afrobarometer..., 2005; Afrobarometer..., 2015]. Для верификации и повышения репрезентативности этих данных они были сопоставлены и, при наличии расхождений, откорректированы в соответствии с результатами ближайших по времени опросов.

Конфессиональное пространство определенной территории представляет собой совокупность образующих его геопространств отдельных религий, которые могут претерпевать трансформацию в рамках двух разнонаправленных процессов, проявляющихся в виде их расширения или сжатия, разделенных во времени стадией территориальной стабилизации. Определение стадий развития геопространств крупнейших религий Нигерии - христианства, ислама, этнорелигий - производилось с помощью комбинации несколько индикаторов: уровня инерционности геопространств религий, оцененного исходя из значения индекса структурных различий Рябцева [Региональная статистика..., 2001, с. 46-47]; уровня территориальной концентрации, определенного с помощью индекса Херфиндаля - Хиршмана (далее - НHI) [Hirschman, 1964, с. 761-762]; динамики значения доли адептов религий в населении Нигерии и ее ATE; скорости и траектории движения демографических центров крупнейших религий, рассчитанных с помощью Geographic Midpoint Calculator [Geographic Midpoint..., 2018] и Latitude/ Longitude Distance Calculator [Latitude/Longitude.... 2018]. Таким образом, мы смогли дать комплексную характеристику развития геопространств крупнейших религий Нигерии за 1952-2015 гг.

Проявляющаяся наряду с континуальностью дискретность конфессионального пространства, а также дифференциация условий его развития определяют неоднородность трансформации геопространств религий: в пределах разных территориальных ячеек геопространство одной и той же религии может проходить разные стадии развития. Определение вклада отдельных АТЕ в процесс трансформации конфессионального пространства Нигерии в целом и геопространств религий в частности производилось нами исходя из среднегодовых темпов прироста доли адептов христианства, ислама и этнорелигий в населении АТЕ за 1952-1963 и 20052015 гг. Если значения этого показателя для той или 
иной религии каждый год в течении 10 лет росли быстрее, чем на $1,2 \%$ (т. е. выше медианного значения по Нигерии), то данный процесс характеризовался как «расширение» геопространства; если убывали быстрее, чем на 1,4\%, - как «сжатие»; если же среднегодовые темпы прироста религии находились в интервале от $-1,4$ до $+1,2 \%$ - как «стабилизация». В настоящей работе нас интересовали трансформационные процессы, поэтому далее нами рассматривались только АТЕ, отвечающие двум условиям: во-первых, в их пределах происходило расширение или сжатие геопространств религий; во-вторых, рассматриваемая религия исповедуется значительным ${ }^{1}$ числом адептов в пределах данной территориальной ячейки [Захаров и др., 2020б].

В качестве основного источника данных о конфликтах в Нигерии нами использовалась база данных ACLED - Armed Conflict Location \& Event Data Project [Africa..., 2018], содержащая информацию о месторасположении, количестве столкновений ${ }^{2}$ и жертв, акторах конфликтов в Нигерии с 1997 по 2017 г. Для дальнейшего анализа нами были использованы следующие из них: 1) количество столкновений; 2) численность жертв (смертей); 3) доля столкновений без жертв; 4) доля столкновений с жертвами; 5) масштабность столкновений; 6) среднее число жертв одного столкновения с жертвами. В совокупности эти характеристики позволили дать комплексную оценку конфликтов, в частности их масштабности (оцененной исходя из среднего числа жертв одного столкновения) и жестокости (доля столкновений с жертвами) в пределах каждой отдельной АТЕ Нигерии. Для сопоставления полученных результатов о трансформации конфессионального пространства Нигерии и локализации конфликтов в стране применялся сравнительно-картографический метод.

В силу того, что развитие конфессионального пространства любой территории во многом носит унаследованный характер [Сафронов, 2013], нами учитывалась специфика историко-географического распространения в Нигерии ислама и христианства.

\section{РЕЗУЛЬТАТЫ ИССЛЕДОВАНИЙ И ИХ ОБСУЖДЕНИЕ}

В общем контексте историко-географического развития крупнейших религий Нигерии выделяется три региона. Во-первых, «хаусаленд» (города-госу-

Для устранения эффекта низкой базы нами установлен порог в $13 \%$, что соответствует началу фазы устойчивого замещения в модели конкурентного развития конфессионального геопространства [Горохов, 2020, с. 133].

${ }^{2} \mathrm{~B}$ базе данных ACLED указана геолокация и дата событий (events), носящих насильственный характер. В тех случаях, когда событие продолжается больше суток, оно фиксируется как несколько событий [ACLED Codebook..., 2019]. дарства хауса) в северной части Нигерии, куда ислам начал проникать еще в IX в. из соседних империй (Канем, Мали, Сонгай, а затем Борно), в которых он имел статус государственной религии, но окончательно закрепился здесь только после джихада фульбе в XIX в. Во-вторых, «игболенд» (государства игбо) на юго-востоке Нигерии, где активная экспансия христианства началась только в середине XIX в., хотя первые попытки христианизации игбо были предприняты еще в XV в. В-третьих, «йорубаленд» (государства йоруба) на юго-западе Нигерии, где распространение христианства и ислама началось фактически в одно и то же время и шло довольно медленно. При этом в ходе длительного сосуществования ислама и христианства на этой территории серьезных противоречий между ними не возникало. Более того, здесь получили развитие уникальные примеры синкретизма, связывающие ислам, христианство и, в определенной степени, этнорелигии в единую религию - «христлам» (Christlam). Здесь также возникла одна из самых известных афрохристианских церквей - аладура. Однако численность приверженцев этих верований по нигерийским меркам невелика [Greenfield, Droogers, 2001; Umoh, 2013].

Несмотря на длительное присутствие ислама и активную деятельность христианских миссионеров, к началу XX в. крупнейшим комплексом верований Нигерии оставались этнорелигии (67,1\% населения), адепты которых составляли большинство населения среди йоруба и особенно игбо. Ислам исповедовало 29,6\% населения страны, христианство - 2,8\% [Brown, James, 2019]. С того времени конфессиональная структура населения Нигерии претерпела масштабные изменения, связанные с вытеснением этнорелигий сначала исламом, а затем христианством. В колониальный этап ислам активно расширял свое геопространство за счет сжатия геопространства этнорелигий в центральной части страны. Благодаря этому, уже к 1930 г. в Нигерии установился паритет этих религий, а к 1963 г. ислам стал крупнейшей религией Нигерии. В то же время христиане, несмотря на быстрый рост численности, представляли меньшинство - в 1910 г. их доля в населении составляла лишь $2,8 \% ; 12,4 \%$ - в 1952 г. и $17,8 \%$ - в 1963 г. [Brown, James, 2019]. Стремительное расширение геопространства христианства в постколониальный этап за счет, прежде всего, юго-восточных штатов в Нигерии привело к установлению паритета христианства и ислама, который сохраняется вплоть до настоящего времени (табл.).

Имеющиеся данные по АTЕ Нигерии за 19522015 гг. охватывают период наиболее интенсивного взаимодействия религий страны. В течение этого времени происходило увеличение количества АТЕ, для конфессионального пространства которых была 
Динамика геопространства крупнейших религий Нигерии в 1910-2015 гг.

\begin{tabular}{|l|c|c|c|c|c|c|c|c|c|c|c|}
\hline \multirow{2}{*}{ Религия } & \multicolumn{5}{|c|}{ Доля в населении, \% } & $\begin{array}{c}\text { Скорость } \\
\text { ДЦ, км/год }\end{array}$ & $\begin{array}{c}\text { Индекс } \\
\text { Рябцева }\end{array}$ & \multicolumn{3}{c|}{ ННІ } \\
\cline { 2 - 12 } & 1910 & 1952 & 1963 & 2005 & 2015 & $1952-2015$ & $1952-2015$ & 1952 & 1963 & 2005 & 2015 \\
\hline Ислам & 29,6 & 44,9 & 47,2 & 45,2 & 44,0 & 1,10 & 0,029 & 714 & 637 & 602 & 615 \\
Христианство & 2,8 & 12,4 & 17,8 & 46,7 & 47,9 & 1,73 & 0,218 & 756 & 591 & 470 & 469 \\
Этнорелигии & 67,1 & 42,5 & 28,5 & 7,9 & 7,5 & 6,16 & 0,781 & 453 & 467 & 1073 & 4602 \\
\hline
\end{tabular}

Примечание: рассчитано и составлено автором по [Brown, James, 2019; Ostien, 2012; Afrobarometer..., 2005; Afrobarometer..., 2015].

характерна стабилизация. Параллельно с этим зона трансформации конфессионального пространства Нигерии претерпевала стягивание - к 2005-2015 гг. она представляла собой диагонально вытянутый пояс, в пределах которого происходило расширение и сжатие геопространств ислама и христианства (рис. 1).
Христианство. Геопространство христианства, представленное преимущественно протестантизмом, претерпело территориальную деконцентрацию и существенное расширение. Так, в 1952 г. значение НHI составляло 756, а более половины его адептов были сконцентрированы на

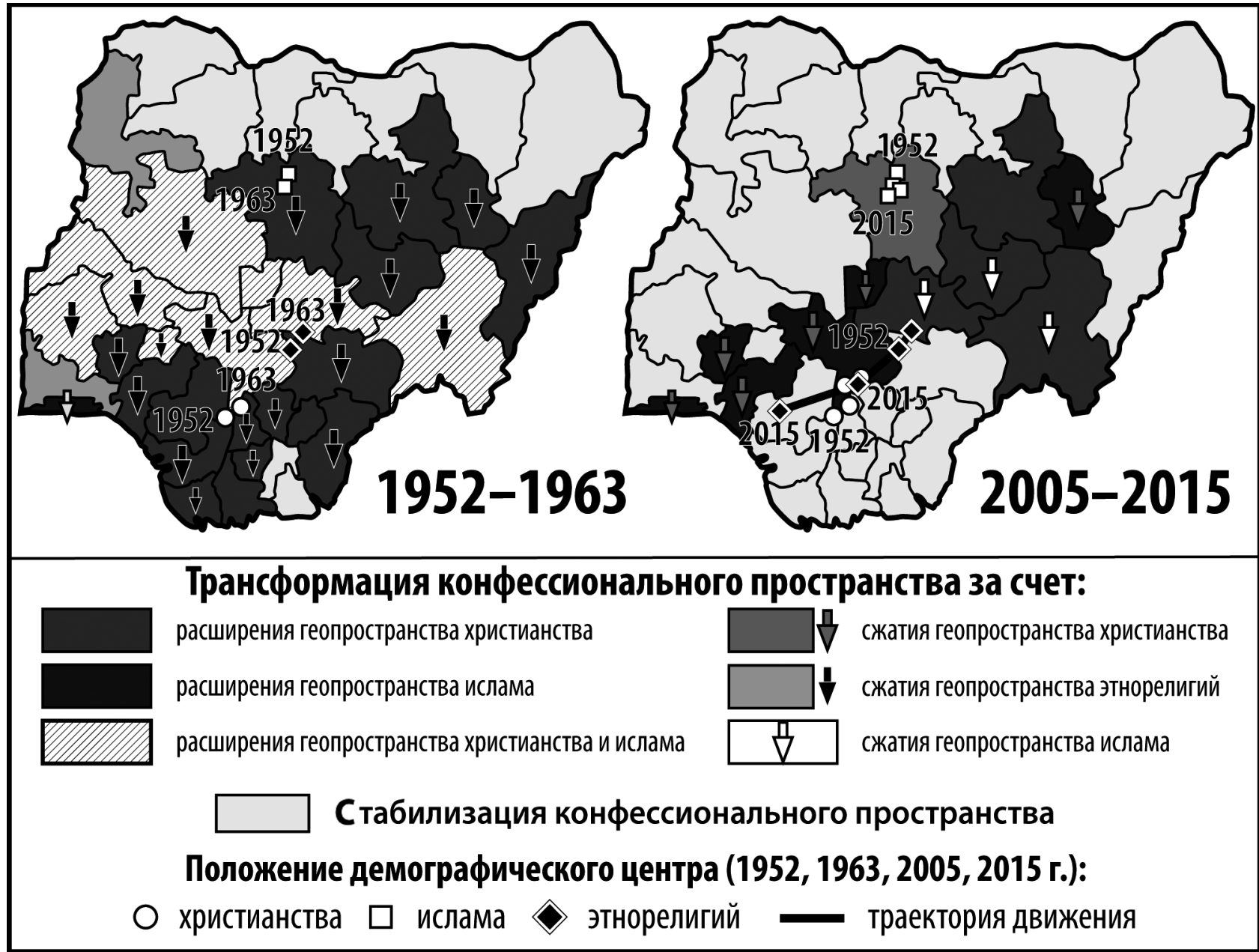

Рис. 1. Трансформация конфессионального пространства Нигерии в 1952-2015 гг. Рассчитано и составлено автором по [Ostien, 2012; Afrobarometer..., 2005; Afrobarometer..., 2015]

Fig. 1. Transformation of the Nigerian religious landscape, 1952-2015.

Calculated by the author after [Ostien, 2012; Afrobarometer..., 2005; Afrobarometer..., 2015] 
территории современных штатов: Аква-Ибом, Абия, Имо, Осун, Ондо. В 2015 г. в пяти крупнейших христианских штатах (Лагос, Риверс, Анамбра, Бенуэ, Имо) проживало лишь $34,1 \%$ адептов этой религии, а значение ННІ снизилось до 469. Территориальные сдвиги внутри геопространства христианства в соответствии со значением индекса Рябцева $(0,218)$ характеризуются как «существенные». Демографический центр этой религии в Нигерии за тот же период сместился в северо-западном направлении на 108,9 км со средней скоростью 1,73 км/год (см. табл., рис. 1).

Таким образом, преобладающим процессом, обусловливающим трансформацию геопространства христианства в 1952-1963 гг., было его масштабное расширение, в первую очередь, на юге страны. Затем этот процесс замедлился и стал развиваться в северо-восточном направлении: в 2005-2015 гг. расширение геопространства христианства происходило только в четырех штатах - Плато, Гомбе, Адамава, Тарабе. В других АТЕ Нигерии получил распространение обратный процесс, который со временем усилился. Так, в 1952-1963 гг. сжатие был характерно только для Лагоса, а в 2005-2015 гг. в него оказались вовлечены Ондо, Осун, Коги, Федеральная столичная территория (ФСТ) Абуджа, Кадуна.

Ислам. До 2005 г. геопространство ислама претерпевало медленную территориальную деконцентрацию, а в последующее десятилетие наметился обратный тренд. Так, значение НHI с 1952 по 2005 г. снизилось до 602, а затем в 2015 г. увеличилось до 615. Вместе с этим вклад пяти крупнейших мусульманских штатов в общую численность соответствующей религиозной общины снизился с $48,7 \%$ в 1952 г. до 41,2\% в 2005 г., а затем вырос до 41,8\%. Территориальная структура геопространства ислама при этом не изменилась - индекс Рябцева составил 0,029 («тождественность структур»). Несмотря на более высокую инерционность в сравнении с христианством, с 1952 по 2005 г. геопространство ислама расширялось на юго-восток - демографический центр этой религии преодолел 69,1 км в югюго-западном направлении со скоростью 1,1 км/год (см. табл., рис. 1).

Основным процессом трансформации геопространства ислама в данный период было ограниченное по масштабам расширение преимущественно в центральных и юго-западных штатах Нигерии. Как и в случае христианства, в течение рассматриваемого периода этот процесс замедлялся: если в 19521963 гг. он наблюдался в 11 АТЕ страны, то в 20052015 гг. их число сократилось до пяти. В последнее десятилетие рассматриваемого интервала геопространство ислама претерпело сжатие в центре и на востоке страны - в штатах Насарава, Плато, Тараба.
Этнорелигии. Наименьшей инерционностью характеризуется геопространство этнорелигий, которое под давлением христианства и ислама претерпело сжатие, а затем фрагментацию, т. е. перестало образовывать единое целое. Если в 1953 г. адепты этнорелигий были размещены по территории страны равномерно (HНI - 453), то в 2015 г. они были представлены на территории лишь трех штатов (Дельта, Лагос, Огун), а значение ННI возросло до 4602. Территориальная структура геопространства этнорелигий в 2015 г. стала «противоположной» по сравнению с таковой в 1952 г. Демографический центр за тот же период преодолел рекордные 388,3 км преимущественно в юго-западном направлении со средней скоростью 6,16 км/год (см. табл., рис. 1). Ведущим процессом в трансформации геопространства этнорелигий в 1952-2015 гг. было сжатие, интенсивность которого сокращалась по мере конверсии их адептов в христианство на юговостоке страны и в ислам на севере и северо-востоке. В связи с истощением конверсионного ресурса к 2005-2015 гг. в Нигерии не осталось штатов, в пределах которых геопространство этнорелигий претерпевало бы сжатие, а их адепты составляли бы значительную долю населения.

В рассматриваемый период крупнейшие религии Нигерии отличались устойчивостью к замещению. Наименее устойчивым было геопространство этнорелигий, которое проходило стадию сжатия. Так, в 1952 г. адепты этнорелигий составляли $67,1 \%$ населения Нигерии и преобладали в 11 штатах, в семи составляли значительную долю в населении и еще в восьми штатах наблюдался паритет этнорелигий и мировых религий (рис. 2). Уже к 2005 г. их доля сократилась до 7,9\%. Геопространство ислама характеризовалось высокой устойчивостью - его замещение христианством в исследуемый период завершилось только в Лагосе, Осуне (2005) и Плато (2015). Однако в первых двух штатах к 2015 г. вновь установился их паритет, что обусловлено миграционным приростом мусульман, представленных преимущественно фульбе из северной Нигерии. В то же время замещение христианства исламом не завершилось ни в одной из территориальных единиц Нигерии (см. рис. 2).

В течение 1952-2015 гг. геопространства ислама и христианства, как отмечалось выше, претерпели расширение, прежде всего, за счет сжатия геопространства этнорелигий в разных АТЕ Нигерии, но происходило это с разной скоростью. Так, с 1952 г. в девяти территориальных единицах, где этнорелигии замещались преимущественно христианством (без учета тех, где замещение уже произошло), в настоящее время преобладают христиане. В то же время в восьми территориальных единицах, где 


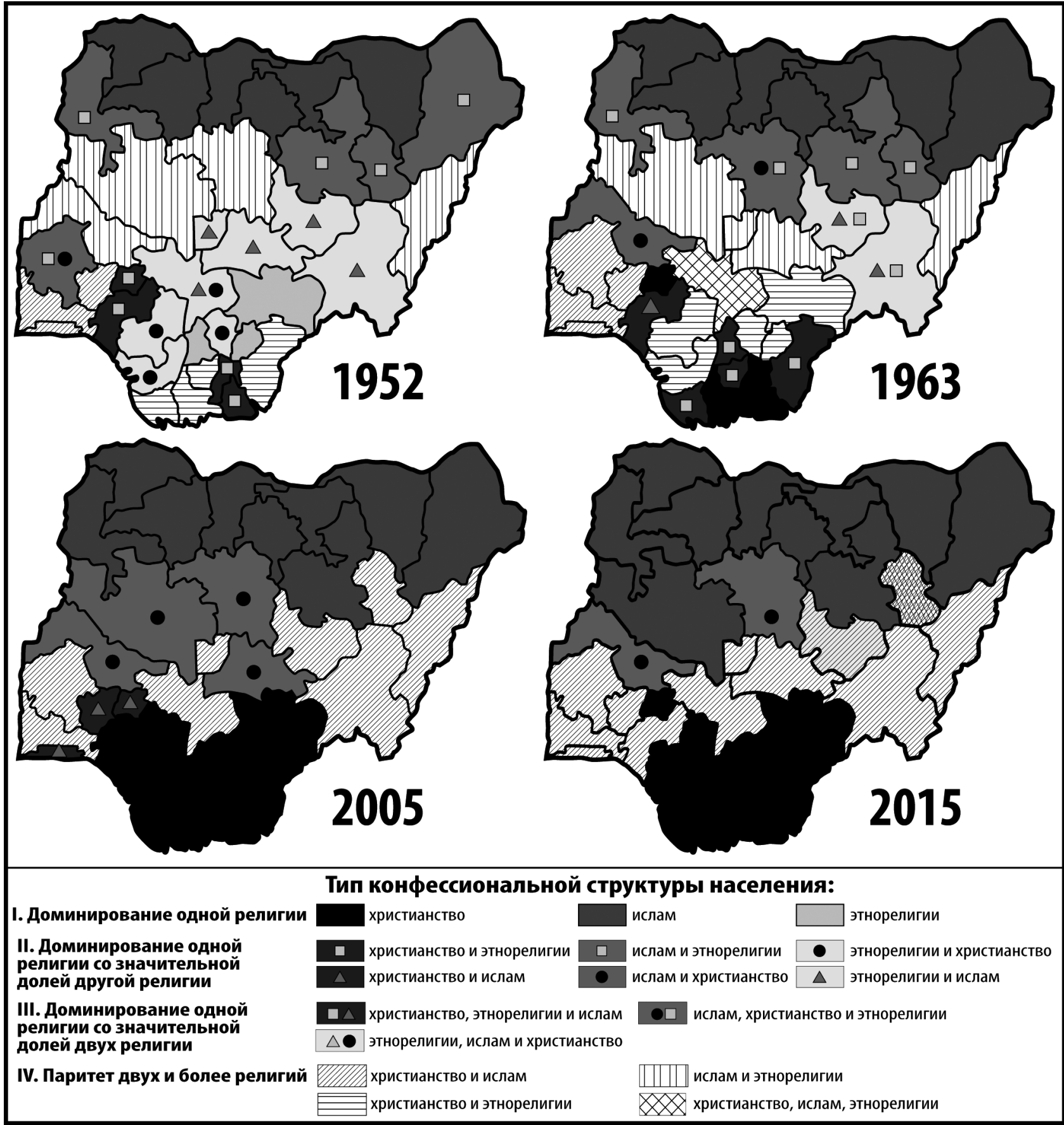

Рис. 2. Типы конфессиональной структуры штатов Нигерии в 1952-2015 гг. Рассчитано и составлено автором по [Ostien, 2012; Afrobarometer..., 2005; Afrobarometer..., 2015]

Fig. 2. Types of religious structure in the states of Nigeria, 1952-2015.

Calculated by the author after [Ostien, 2012; Afrobarometer..., 2005; Afrobarometer..., 2015]

этнорелигии замещались преимущественно исламом, этот процесс завершился только в Нигере и Кадуне. В остальных случаях в конкуренцию вступило христианство, и в этих штатах устанавливался паритет мировых религий. То же произошло в штатах Ойо и Коги, где христианство и ислам распространялись одновременно. При этом в первом случае доля христиан за весь рассматриваемый период увеличивалась высокими темпами - с 25,7\% в
1952 г. до 53,2\% в 2015 г., а мусульман - сокращалась с 50,4 до 46,2\%. Во втором случае доля адептов христианства к 2005 г. возросла с 18,5 до 51,5\%, а ислама - с 22,5 до 48,5\%. В последующее десятилетие конфессиональная структура штата изменилась под влиянием миграционного прироста мусульман, доля которых возросла до 59,5\%, а христиан сократилась до 40,5\%. Таким образом, христианство замещало другие религии в Нигерии более эффективно 
по сравнению с исламом. Более того, христианству удавалось увеличивать долю последователей в ряде традиционно мусульманских штатов, даже несмотря на действующие в них законы шариата - Гомбе $(36,7 \%$ в 2015 г.), Кадуне $(17,5)$, Баучи $(14,5)$, Сокото $(6,8)$, Йобе $(6,6)$ и т. д. [Ostien, 2012; Afrobarometer..., 2005; Afrobarometer..., 2015].

Расширение геопространства христианства и ислама привело к образованию диагонально вытянутого пояса штатов, конфессиональное пространство которых в настоящее время претерпевает трансформацию - здесь мировые религии взаимодействуют наиболее интенсивно. Этот пояс характеризуется паритетом христианства и ислама и включает в себя 11 ATE: Лагос, Огун, Ойо, Осун, Ондо, Коги, Насарава, ФСТ Абуджа, Тараба, Адамава и Гомбе. В населении штатов к юго-востоку от него преобладают христиане, к северу, за исключением Экити и Плато, - мусульмане (см. рис. 2). Результатом трансформации геопространств крупнейших религий Нигерии стала перестройка конфессиональной структуры ее населения: к северо-востоку от зоны трансформации в настоящее время преобладает ислам, к юго-востоку - христианство. При этом расширение геопространства ислама на юг обеспечивалось в основном миграционным приростом мусульман, а расширение геопространства христианства на север и северо-восток осуществлялось, в первую очередь, за счет конверсии.

Сложившаяся территориальная структура конфессионального пространства Нигерии на фоне серьезных социально-экономических диспропорций между южными и северными штатами способствовала увеличению конфликтности в стране, при этом крупнейшие субъекты конфликтов аффилируют себя с религией. Среди них выделяется исламистская террористическая организация «Боко Харам». Возникнув в штате Борно, эта группировка смогла установить контроль над значительной частью территорий на северо-востоке Нигерии (в штатах Борно, Йобе, Адамава, Баучи, Гомбе), а затем расширить ареал своей деятельности в соседние страны (Камерун, Нигер, Чад). Более того, в 2015 г. «Боко Харам» официально вошла в глобальную исламистскую террористическую сеть - после того как ее лидер присягнул на верность «Исламскому государству» (запрещено в РФ). Насильственные действия этой группировки направлены, во-первых, против властей Нигерии, которые обвинялись ими в поощрении христианизации страны и распространении «западной секулярной буржуазной культуры»; во-вторых, против населения, не разделяющего их религиозных и идеологических убеждений (в т. ч. против мусульман). Сейчас активность «Боко Харам» заметно снизилась, но угроза региональной безопасности по-прежнему высока [Денисова, 2019; Brechenmacher, 2019].

В последнее время отмечается активизация группировок фульбе, чья деятельность сосредоточена в «среднем поясе» страны (Middle Belt), ряде северных и юго-восточных штатов (рис. 3). По сравнению с «Боко Харам» данные группировки менее организованы, а их действия преследуют скорее прагматические, чем идеологические задачи. Засухи, снижение плодородия почв на фоне политической нестабильности на севере Нигерии вызвали массовые миграции фульбе на юг страны. Возникшие в результате этого столкновения имеют три измерения: религиозное (мусульмане против христиан), этническое (фульбе против других народов, в т. ч. хауса и канури), культурное (кочевой север против оседлого юга) [The Fulani..., 2018].

Из 295 столкновений в 2017 г. субъектами почти $80 \%$ из них были «Боко Харам» и группировки фульбе, при этом бо́льшая часть из этих конфликтов унесла жизни людей [Africa..., 2018]. Помимо вышеназванных субъектов столкновения, на юго-востоке страны оперируют многочисленные этнические, а на севере - религиозные группировки. Среди последних превалируют суннитские, действующие против христиан, а также шиитов и ахмадийя в штатах Сокото, Кебби, Кадуна, Кано, Плато (см. рис. 3).

Жестокость конфликтов в Нигерии повышается по мере продвижения на северо-восток, т. е. соответствует вектору расширения геопространства христианства. Так, среднее количество жертв одного столкновения в штате Кадуна составило 12,9; Плато - 11,4; Тараба - 9,8; Адамава - 9,2; Кано 8,6 ; Гомбе - 6,0. Вместе с тем в ряде штатов, где наблюдается паритет мировых религий, увеличивается доля столкновений с жертвами: например, в Тараба этот показатель достигает 74,6\%, Адамава $-66,2 \%$, Бенуэ - 63,6\%, Плато - 63,2\%, Гомбе $61,9 \%$, Кадуна $-59,9 \%$ и т. д. Однако наибольшей масштабностью и жестокостью отличаются столкновения в Борно, где сосредоточена деятельность «Боко Харам». С 1997 по 2017 г. на этот штат пришлось 1580 столкновений $(15,8 \%$ их общего количества в стране, при этом $4 / 5$ из них имеют жертвы), унесших жизни более 20 тыс. человек $(36,6 \%)$, их среднее количество за столкновение превышает 13,1 [Africa..., 2018].

Наименее конфликтными, несмотря на паритет христианства и ислама, являются юго-западные штаты Нигерии, а также ФСТ Абуджа. Бо́льшая часть возникающих здесь конфликтов приходится на протесты, цель которых заключается в изменении государственной политики, улучшении качества жизни населения и т. д. Относительно низкая жестокость столкновений здесь объясняется как 
сравнительно высоким уровнем социально-экономического развития, так и длительной историей взаимодействия христианства и ислама на этой территории - обе религии считаются здесь «традиционными». На общем фоне выделяются штаты Лагос и Квара: первый - по количеству столкновений (896 - второе место после Борно); второй - по доле столкновений с жертвами (42,6\%) [Africa..., 2018]. В первом случае это связано в большей мере с криминогенной обстановкой крупнейшего города Африки южнее Сахары. Во втором случае значительная часть конфликтов связана с протестами, политической борьбой, преступностью и в меньшей степени - с межобщинными противостояниями.

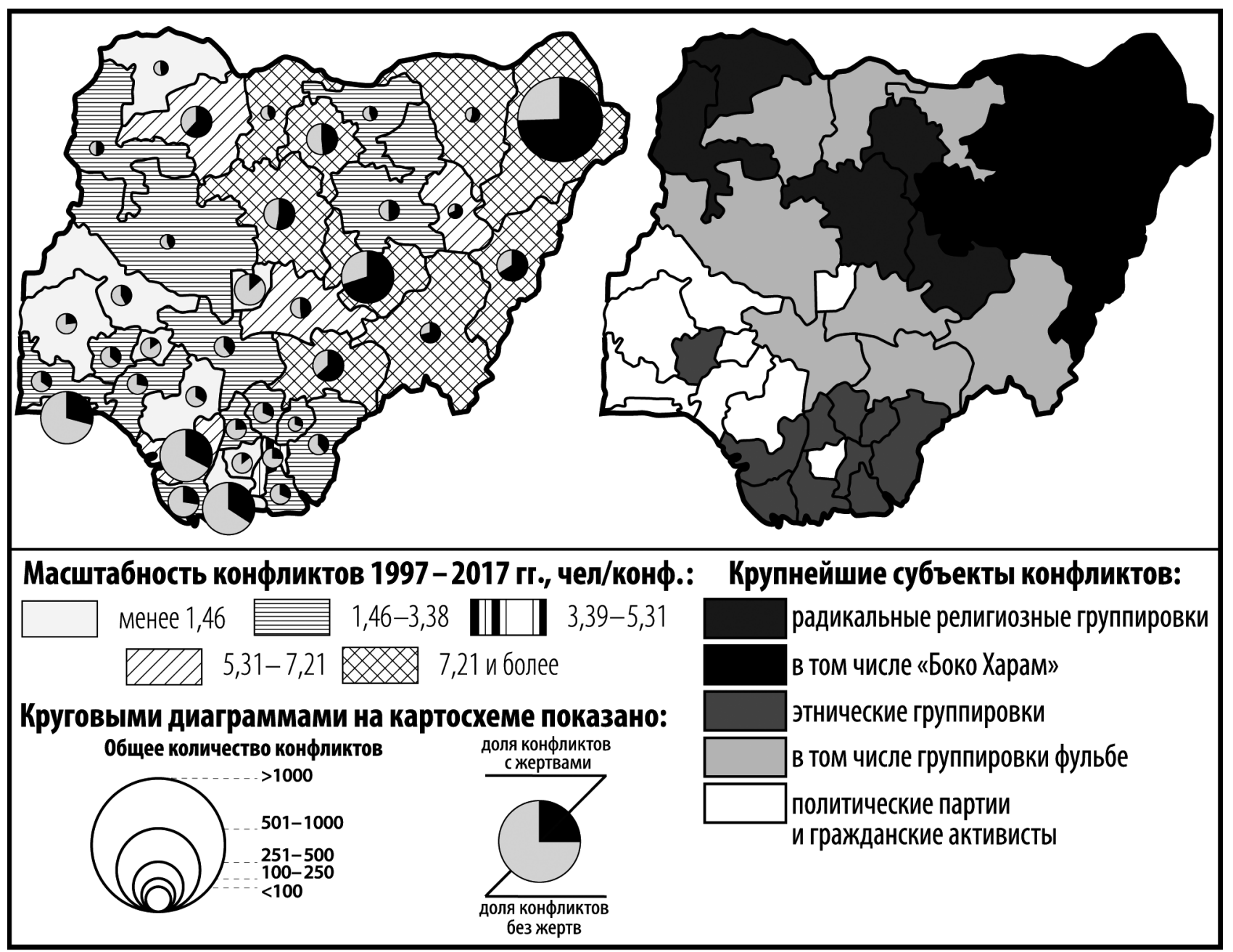

Рис. 3. География столкновений в Нигерии в 1997-2017 гг. Рассчитано и составлено автором по [Africa..., 2018]

Fig. 3. Geography of conflicts in Nigeria, 1997-2017.

Calculated by the author after [Africa..., 2018]

Таким образом, сложившаяся в ходе стремительной трансформации структура конфессионального пространства Нигерии оказала негативное влияние на межобщинные взаимоотношения в этой стране. В результате возникли условия для мобилизации религиозного сознания населения целых штатов или их районов отдельными лидерами, что способствовало популяризации радикальных идей, часто мимикрирующих под религиозные. В настоящее время такая ситуация имеет место в северной части Нигерии («Боко Харам» и другие террористи- ческие группировки). В прошлом веке схожая ситуация была характерна для юго-востока страны (например, «культ тайной войны» ${ }^{3}$, направленный против миссионеров и колонизаторов в дельте Нигера [The Cambridge History..., 1985, p. 290]). Если рассматривать развитие межобщинных конфликтов в теоретических рамках настоящего исследования, то их можно интерпретировать как реакцию одной религии на замещение и активизацию миссионер-

${ }^{3}$ Яз. игбо - Ibo-Ekumeku. 
ской деятельности другой. Примечательно, что радикализация религиозной общины начинается в ее историческом «ядре» (обычно гомогенном с точки зрения конфессиональной структуры населения), а не в зоне взаимодействия геопространств религий. При этом, судя по имеющимся данным, масштаб и жестокость возникающих конфликтов тем выше, чем стремительнее протекают процессы трансформации в конфессиональном геопространстве. Вместе с этим необходимо подчеркнуть, что ни христианство, ни ислам в Нигерии не представляют собой «монолитных блоков», напротив, они образуют динамичную систему взаимодействующих между собой геопространств отдельных религиозных направлений, между которыми нередко возникают противоречия. В связи с этим важным направлением дальнейших исследований может стать изучение внутрирелигиозной конкуренции, ее влияния на локализацию и специфику протекания конфликтов между направлениями одной религии.

\section{ВЫВОДЫ}

За сравнительно короткий период конфессиональное пространство Нигерии претерпело масштабную трансформацию, вызванную замещением этнорелигий исламом, а затем христианством. В течение колониального этапа истории страны ислам активно расширял свое геопространство за счет сокращения этнорелигий, благодаря чему уже к 1963 г. он стал крупнейшей религией в Нигерии.
В постколониальный этап христианство замещало другие религии в территориальных единицах этого государства более эффективно по сравнению с исламом, что привело к установлению их паритета, который сохраняется до сих пор.

Расширение геопространства христианства и ислама привело к образованию диагонально вытянутого пояса, включающего штаты с паритетом мировых религий. Данный пояс разделил страну на христианский юг и мусульманский север. Сложившаяся поляризованная территориальная структура конфессионального пространства Нигерии на фоне серьезных социально-экономических диспропорций между южными и северными штатами способствовала увеличению конфликтного потенциала этой страны.

Рост конфликтности в Нигерии обусловлен не только межрелигиозной, но и внутрирелигиозной конкуренцией, о чем, в частности, свидетельствует интенсификация столкновений между шиитскими и суннитскими группировками на севере страны.

Жестокость возникающих в Нигерии столкновений повышается по мере движения на северо-восток, т. е. соответствует вектору расширения геопространства христианства. При этом крупнейший субъект этого противостояния - группировка «Боко Харам» - возник как ответная реакция на конкуренцию с христианством в «ядре» геопространства ислама, а не в зоне непосредственного взаимодействия мировых религий.

Благодарности. Статья подготовлена по материалам исследований по темам ГЗ Института географии РАН № 0148-2019-0008 и Института Африки РАН № 0192-2019-0021. Методика исследования разработана в рамках темы ГЗ № 0192-2019-0021; расчеты выполнены в рамках темы ГЗ № 0148-2019-0008.

\section{СПИСОК ЛИТЕРАТУРЫ}

Горохов С.А. География религий: Циклы развития глобального конфессионального пространства. М.: Юнити-Дана, 2020. 235 с.

Денисова Т.С. Нигерия: итоги первого срока президентства Мохаммаду Бухари и всеобщие выборы 2019 года // Азия и Африка сегодня. 2019. № 8. С. 37-42. DOI: $10.31857 / \mathrm{S} 032150750005775-4$.

Захаров И.А., Горохов С.А., Дмитриев Р.В. Роль религиозного фактора в формировании конфликтных зон в Африке // Вестн. СПб. ун-та. Науки о Земле. 2020а. № 65(4). C. 640-653. DOI: 10.21638/spbu07.2020.402.

Захаров И.А., Горохов С.А., Дмитриев Р.В. Трансформация конфессионального пространства Африки в XX - начале XXI века // Известия РАН. Серия географическая. 2020б. Т. 84. № 3. С. 359-368. DOI: $10.31857 / \mathrm{S} 2587556620030127$.

Заяч Д.В. Географические типы сепаратизма // Проблемы геоконфликтологии. Т. 1 / под ред. Н.С. Мироненко. М.: Пресс-Соло, 2004. С. 36-58.
Заяи Д.В. Феномен непризнанных государств в современном мире // Географическая среда и живые системы. 2020. № 1. C. 53-69. DOI: 10.18384/2712-7621-2020-1-53-69.

Колосов А.В., Себенцуов А.Б., Туров Н.Л. Неконтролируемые территории в современном мире: теория, генезис, типы, динамика // Контуры глобальных трансформаций: политика, экономика, право. 2021. Т. 14. № 1. C. 23-51. DOI: 10.23932/2542-0240-2021-14-1-2.

Попов Ф.А. География сецессионизма в современном мире. М.: Новый Хронограф, 2012. 672 с.

Региональная статистика: учебник / отв. ред. В.М. Рябцев, Г.И. Чудилин. М.: Московский издательский дом, 2001. $380 \mathrm{c}$.

Сафронов С.Г. Территориальная структура и динамика современного конфессионального пространства России // Региональные исследования. 2013. № 4. С. 87-99.

Себенцов А.Б., Колосов В.А. Феномен неконтролируемых территорий в современном мире // Полис. 2012. № 2 . C. $31-46$. 
Фитуни Л.Л. Трансконтинентальный сетевой терроризм АНГА // Ученые записки Института Африки. 2015. № 2. C. 95-99.

Brazhalovich F.L., Klyuchnikov M.I., Lukyanov A.I. The Political-Geographical Aspects of Problematic Statehood (Exemplified by Somalia), Geography and Natural Resources, 2016, vol. 37, no. 3, p. 264-270.

Dmitriev R.V., Gorokhov S.A., Zakharov I.A. Spatial Expansion of Islamic Extremism in the Lake Chad Basin: Current Situation and Prospective Directions, Filosofia Theoretica: Journal of African Philosophy, Culture and Religions, 2020, vol. 9, no. 1, p. 47-61, DOI: 10.4314/ft.v9i1.4.

Greenfield S.M., Droogers A.F. Reinventing Religions: Syncretism and Transforming in Africa and Americas, Rowman \& Leiitlefield, 2001, 270 p.

Hirschman A.O. The Paternity of an Index, The American Economic Review, 1964, vol. 54, no. 5, p. 761-762.

Ostien P. Percentages by Religion of the 1952 and 1963 Populations of Nigeria's Present 36 States, NRN (Nigeria Research Network) Background Paper, 2012, no. 1, 14 p.

The Cambridge History of Africa, vol. 6, 1870-1905, O. Roland and G.N. Sanderson (eds.), Cambridge, Cambridge University Press, 1985,956 p.

Umoh D. Superstition and Syncretism: Setbacks to Authentic Christian Practice in Africa, International Journal of Humanities and Social Science Invention, 2013, vol. 2, iss. 71, p. 32-40.

Walther $O$. A Mobile Idea of Space. Traders, Patrons and the Cross Border Economy in Sahelian Africa, Journal of Borderlands Studies, 2009, vol. 24, no. 1, p. 34-46, DOI: 10.1080/08865655.2009.9695716.

\section{Электронные ресурсы}

ACLED Codebook, URL: https://www.acleddata.com/ download/2827/ (access date 16.05.2018).

Africa 1997 - Present (Data Through 12 May 2018), ACLED (The Armed Conflict Location \& Event Data Project), URL: https://www.acleddata.com/download/2909/ (access date 16.05.2018).

Afrobarometer data R2 Nigeria, 2015, URL: http://afrobarometer.org/ (access date 19.02.2018).

Afrobarometer data R3 Nigeria, 2005, URL: http://afrobarometer.org/ (access date 19.02.2018).

Brechenmacher $S$. Stabilizing Northeast Nigeria After Boko Haram, Carnegie Endowment for International Peace, URL: https://carnegieendowment.org/files/Brechenmacher_Nigeria final.pdf (access date 11.11.2020).

Brown D., James P. Religious Characteristics of States Dataset Project - Demographics v. 2.0 (RCS-Dem 2.0), Countries Only, 2019, URL: http://www.thearda.com/ Archive/Files/Descriptions/RCSDEM2.asp (access date 02.06.2019).

Geographic Midpoint Calculator, URL: http:/geomidpoint. $\mathrm{com} /$ (access date 20.02.2018).

Latitude / Longitude Distance Calculator, URL: https://www. nhc.noaa.gov/gccalc.shtml (access date 20.02.2018).

The Fulani Ethnic Militia in Nigeria, 2018, URL: https:// www.acleddata.com/wp-content/uploads/2018/03/Fulani.png (access date 12.11.2020).

Tolerance and Tension: Islam and Christianity in Sub-Saharan Africa, URL: https://www.pewforum.org/2010/04/15/ executive-summary-islam-and-christianity-in-subsaharan-africa/ (access date 10.11.2020).

\title{
COMMUNAL CONFLICTS IN THE CONTEXT OF THE RELIGIOUS LANDSCAPE TRANSFORMATION (CASE STUDY OF NIGERIA)
}

\author{
I.A. Zakharov ${ }^{1}$, R.V. Dmitriev ${ }^{2}$ \\ ${ }^{1,2}$ Institute of Geography, Russian Academy of Sciences \\ ${ }^{1,2}$ Institute for African Studies, Russian Academy of Sciences \\ ${ }^{1}$ Scientific Researcher; Ph.D. in Geography, Junior Scientific Researcher; e-mail: vanszax@yandex.ru \\ ${ }^{2}$ Senior Scientific Researcher, Ph.D. in Geography; e-mail: dmitrievrv@yandex.ru
}

The article attempts to define spatial mechanisms of emerging conflicts in the context of the transformation of Nigeria's religious landscape. To implement the task, the authors propose a methodology to determine vectors and trends in the transformation of geo-spaces of the country's largest religions (Christianity, Islam and Ethnic religions) within the administrative territorial units of Nigeria. The methodology combines the Ryabtsev index of territorial structure shifts, the Herfindahl-Hirschman index, the dynamics of the share of a certain faith group in population, and the rate and trajectory of the shift of their demographic centers within the country. The results were correlated with the spatial pattern of conflicts location. The conflicts were further analyzed considering their main actors, scale (average number of casualties per conflict) and brutality (share of casualties of a conflict). It was found that the expansion of Christianity and Islam geospaces, primarily at the expense of Ethnic religions geospace, led to the formation of a diagonally elongated belt of states that divides Nigeria into predominantly Christian southeast and predominantly Muslim north. The polarized territorial structure of Nigeria's religious landscape combined with pronounced socio-economic imbalances between the southern and northern states resulted in the growing conflict potential of the country. It is empirically found that the severity of conflicts in Nigeria increases towards the northeast of the country, i.e. along the expansion vector 
of Christianity geo-space. The authors interpret the discovered pattern as a response of Islam geo-space which is replaced by Christianity being more effective in terms of its missionary activity. The most active subjects of conflicts, in particular the «Boko Haram» terrorist group (banned in Russia), have emerged in the historical core of Islam in Nigeria rather than in the zone of direct interaction of world religions. The available data suggest that the faster the religious landscape of Nigeria's states transforms, the higher the scale and severity of conflicts.

Keywords: Africa, geography of religions, religious landscape, religious competition, religious conflict

Acknowledgements. The article covers the materials of the studies carried out under the framework of the state assignments of the Institute of Geography RAS (No. 0148-2019-0008) and the Institute of Africa RAS (No. 0192-2019-0021). Research techniques were developed under the framework of the state assignment No. 0192-2019-0021; calculations were made under the framework of the state assignment No. 0148-2019-0008.

\section{REFERENCES}

Brazhalovich F.L., Klyuchnikov M.I., Lukyanov A.I. The Political-Geographical Aspects of Problematic Statehood (Exemplified by Somalia), Geography and Natural Resources, 2016, vol. 37, no. 3, p. 264-270.

Denisova T.S. Nigeriya: itogi pervogo sroka prezidentstva Mohammadu Buhari i vseobshchie vybory 2019 goda [Nigeria: The Results of Muhammadu Buhari's First Presidential Term and the 2019 General Election], Asia and Africa Today, 2019, no. 8, p. 37-42. (In Russian)

Dmitriev R.V., Gorokhov S.A., Zakharov I.A. Spatial Expansion of Islamic Extremism in the Lake Chad Basin: Current Situation and Prospective Directions, Filosofia Theoretica: Journal of African Philosophy, Culture and Religions, vol. 9, no. 1, 2020, p. 47-61, DOI: 10.4314/ft.v9i1.4.

Fituni L.L. Transkontinental'nyj setevoj terrorizm ANGA [Transcontinental Network Terrorism of Aggressive NonState Actors (Ansa)], Journal of the Institute for African Studies, 2015, no. 2, p. 95-99. (In Russian)

Gorokhov S.A. Geografiya religij: Tsikly razvitiya global'nogo konfessional'nogo prostranstva [Geography of Religions: Development Cycles of the Global Religious Landscape], Moscow, Yuniti-Dana Publ., 2020, 235 p. (In Russian)

Greenfield S.M., Droogers A.F. Reinventing Religions: Syncretism and Transforming in Africa and Americas, Rowman \& Leiitlefield, 2001, 270 p.

Hirschman A.O. The Paternity of an Index, The American Economic Review, 1964, vol. 54, no. 5, p. 761-762.

Kolosov V.A., Sebentsov A.B., Turov N.L. Nekontroliruemye territorii $\mathrm{v}$ sovremennom mire: teoriya, genezis, tipy, dinamika [Uncontrolled Territories in the Contemporary World: Theory, Genesis, Types and Dynamics], Outlines of Global Transformation: Politics, Economics, Law, 2021, vol. 14, no. 1, p. 31-46, DOI: 10.23932/25420240-2021-14-1-2. (In Russian)

Ostien P. Percentages by Religion of the 1952 and 1963 Populations of Nigeria's Present 36 States, Nigeria Research Network, NRN Background Paper, 2012, no. 1, 14 p.

Popov F.A. Geografiya secessionizma v sovremennom mire [Geography of Secessionism in the Modern World], Moscow, Novyj Hronograf, 2012, 672 p. (In Russian)

Regional'naya statistika: uchebnik [Regional Statistics: Student's Book], V.M. Ryabtsev, G.I. Chudilin (eds.), Moscow, Moscow Publ. House, 2001, 380 p. (In Russian)

Safronov S.G. Territorial'naya struktura i dinamika sovremennogo konfessional'nogo prostranstva Rossii [Territorial Structure and Dynamics of the Modern Confessional
Space Russia], Regional'nye issledovaniya, 2013, no. 4 , p. 87-99. (In Russian)

Sebentsov A.B., Kolosov V.A. Fenomen nekontroliruemyh territorij $\mathrm{v}$ sovremennom mire [Phenomenon of uncontrolled territories in modern world], Polis. Political Studies, 2012, no. 2, p. 31-46. (In Russian)

The Cambridge History of Africa, vol. 6, 1870-1905, O. Roland, G.N. Sanderson (eds.), Cambridge, Cambridge University Press, $1985,956 \mathrm{p}$.

Umoh D. Superstition and Syncretism: Setbacks to Authentic Christian Practice in Africa, International Journal of Humanities and Social Science Invention, 2013, vol. 2, no. 71 , p. 32-40.

Walther O. A Mobile Idea of Space. Traders, Patrons and the Cross-Border Economy in Sahelian Africa, Journal of Borderlands Studies, 2009, vol. 24, no. 1, p. 34-46, DOI: 10.1080/08865655.2009.9695716.

Zakharov I.A., Gorokhov S.A., Dmitriev R.V. Rol' religioznogo faktora $\mathrm{v}$ formirovanii konfliktnykh zon v Afrike [The Role of Religious Factor in the Formation of Conflict Zones in Africa], Vestn. SPb. Univ. Earth Sciences, 2020a, no. 65(4), p. 640-653, DOI: 10.21638/ spbu07.2020.402. (In Russian)

Zakharov I.A., Gorokhov S.A., Dmitriev R.V. Transformatsiya konfessional'nogo prostranstva Afriki v XX nachale XXI vekov [Transformation of African Religious Landscape in the 20th and beginning of the $21 \mathrm{st}$ Century], Izvestiya Rossiiskoi akademii nauk, Ser. Geogr., 2020b, vol. 84, no. 3, p. 359-368. DOI: $10.31857 /$ S2587556620030127. (In Russian)

Zayats D.V. Geographical Types of Separatism, Problemy Geokonfliktologii [Problems of Geoconflictology], vol. 1, N.S. Mironenko (ed.), Moscow, Press-Solo Publ., 2004, p. 36-58.

Zayats D.V. Fenomen nepriznannyh gosudarstv v sovremennom mire [The Phenomenon of Unrecognized States in the Modern World], Geographical environment and living systems, 2020, no. 1, p. 53-69, DOI: 10.18384/27127621-2020-1-53-69. (In Russian)

\section{Web sources}

ACLED Codebook, URL: https:/www.acleddata.com/ download/2827/ (access date 16.05.2018).

ACLED. Africa 1997 - Present (Data Through 12 May 2018), URL: https://www.acleddata.com/download/2909/ (access date 16.05.2018). 
Afrobarometer data R2 Nigeria, 2015, URL: http://afrobarometer.org/ (access date 19.02.2018).

Afrobarometer data R3 Nigeria, 2005, URL: http://afrobarometer.org/ (access date 19.02.2018).

Brechenmacher S. Stabilizing Northeast Nigeria After Boko Haram, Carnegie Endowment for International Peace, URL: https:/carnegieendowment.org/files/Brechenmacher_Nigeria_final.pdf (access date 11.11.2020).

Brown D., James P. Religious Characteristics of States Dataset Project - Demographics v. 2.0 (RCS-Dem 2.0), Countries Only, 2019, URL: http:/www.thearda.com/Archive/Files/ Descriptions/RCSDEM2.asp (access date 02.06.2019).
Geographic Midpoint Calculator, URL: http:/geomidpoint. $\mathrm{com} /$ (access date 20.02.2018).

Latitude / Longitude Distance Calculator, URL: https:/www. nhc.noaa.gov/gccalc.shtml (access date 20.02.2018).

The Fulani Ethnic Militia in Nigeria, 2018, URL: https:// www.acleddata.com/wp-content/uploads/2018/03/Fulani.png (access date 12.11.2020).

Tolerance and Tension: Islam and Christianity in Sub-Saharan Africa, URL: https://www.pewforum.org/2010/04/15/ executive-summary-islam-and-christianity-in-sub-saharan-africa/ (access date 10.11.2020). 